\title{
THE SECOND LIFE OF BUNG KARNO ANALYSIS OF THE MYTH (1978-1981)*
}

\author{
Pierre Labrousse
}

"Saya hendak mengepal dunia, ayah"

Sukarno

The assessment of the personality and of the historic role of Sukarno constitutes the theme of an already considerable amount of literature, diverse and sometimes controversial. From the end of the 1920s in the Dutch East Indies his sharp awareness of the colonial system, his political struggle, his exile followed by his sudden rise on the international scene, as well as the rapidity of his decline, alone present the grandeur and excess to feed the popular myths which arose from around 1928.

After March 1966, we are aware of Sukarno's withdrawal from the political scene, of his house arrest under the pretext of an investigation to determine his role in the events of September 30,1965, of his rather hasty-although declared "national" - funeral, and finally of his passage into purgatorial silence by the official erasing of his historical role-particularly in relation to the birth of the Pancasila-and by the embargo on the republishing of his political writings.

The year 1978, with the announcement of the construction of a funerary complex in Blitar dedicated to the Father of the People (Bapak Rakyat), to the Proclaimer of Independence, to the first President of the Republic of Indonesia, ${ }^{1}$ marks the end of this period and the officially controlled liberation of Sukarno's memory. Along with pre-election reasons, we can suppose that mystical motives were also at play: commemoration of the first windu of his death (eight-year cycle), as well as personal ones: asking forgiveness to Bung Karno (minta maaf).

The re-establishment of the memory immediately sparked a surge of commemorative items: articles, popular books sold on the sidewalk, posters, stickers ... which quickly

\footnotetext{
"This article was presented at the Third European Colloquium of Malay and Indonesian Studies, in Naples (June 2-4, 1981). The French version appeared in Archipel 25 (1983): 187-214.

1 See Chronology, p. 177.
} 
forced the government to take authoritarian measures of containment, denouncing the commercialization of the affair.

It is through our best efforts to bring together books published upon this occasion ${ }^{2}$ which are not, strictly speaking, oriented toward a mass audience (reading being a privilege in itself) -as well as newspaper articles-coming for the most part from the Yayasan Idayu, which holds in its possession a remarkable body of documentation ${ }^{3}$ - that we have constituted the corpus of our work.

In comparison with the Sukarnian legend, such as it exists in an oral tradition difficult to delimit, it is evident that these texts, liable to various forms of censorship, ${ }^{4}$ find themselves at odds with what one might hear in private. Writing does not possess the freedom of oral expression, and the information available today-privileged due to its lack of political (and financial!) risks-concerns Sukarno's birth, his childhood, and the period of independence. After 1957, political references are not officially authorized, so that only family anecdotes, marriages, and his international actions with regard to the Third World persist.

With the above limitations, does the corpus still allow an analysis of the complexity of popular representations of Bung Karno? Certainly it does. First of all from the point of view of diversity-images of the man (his culture, women, suffering, and death)-and then from a perspective more difficult to analyze, that would be the correspondence between certain types of images and certain social groups. Finally, along with the permanence of a particularly Javanese vision of the sovereign, we have determined two other poles toward which the memory of Sukarno still seems attracted-Islam and the New Order. And still beyond this-but in a very fragmentary way in our corpus-we find the claiming of the Sukarnian model by two less homogeneous groups, namely, certain factions of the opposition, and the young people who no longer maintain toward this Father they never knew, the inhibitions of their elders.

To be complete, this study should also have focused on the authors and editors, in order to verify the rumors concerning the intention of these publications: former PNI circles, new opposition, family clan, or simply sensible merchants. To tell the truth, we had neither the time nor the conviction to be able to come up with facts sufficiently established to appear in a publication such as this. Nevertheless, this dimension of the subject does not escape us, but allows only difficult-to-verify intuitions.

\section{Supernatural Powers}

The idea of political power resulting from the convergence of a personal predestination with supernatural powers can doubtlessly be linked to certain Javanese beliefs, and is still largely shared by the lower strata of Indonesian society. Nor is it surprising that the Javanese, and Java in general, play a particularly active role in the elaboration of the myth. In this vision of power, no rupture of continuity exists between royal and presidential office, nor between mythical ancestry and family descent, and it would be equally easy to find traces of this phenomenon in the current regime as in the Sukarnian legend. The glory of

\footnotetext{
2 See Bibliography, below, pp. 195-96.

${ }^{3}$ The Yayasan Idayu, which we deeply thank for the welcome we received, collects press clippings as well as iconography relating to Sukarno. It has published a complete bibliography: Bung Karno, Sebuah bibliografi (Jakarta: Yayasan Idayu, 1979).

4 Such as, for example, Wasiat Bung Karno, edited by Gunung Agung in 1978.
} 


\section{Chronology of Bung Karno's Revival}

June 21, 1970 Death of Engineer Sukarno. National funeral as the Proclaimer of Independence. He is buried in Blitar near his mother. Extinguishment of the judicial action concerning his role during the events of 1965.

January 24, 1978 Before members of the PDI celebrating its fifth anniversary in Solo, Minister of Information Ali Murtopo announces that "Pak Harto, both personally and in his capacity as President of the Republic, has decided to renovate Bung Karno's tomb."

March 4, 1978 Pilgrimage to Blitar by Ali Murtopo and members of a seminar of the East Java PDI. The main principles of the renovation are announced: tomb, oratory chapel, and inscriptions: "Penyambung lidah rakyat, Pemimpin Bangsa Indonesia, Proklamator Republik Indonesia" (Spokesman of the people, Leader of the Indonesian Nation, Proclaimer of the Republic of Indonesia).

May 1978 Family and national squabbles over the site of the tomb. Various proposals regarding the site: close to his mother in Blitar; in a rustic site of the Priangan where he conceived of Marhaenism; in the Monumen Nasional (Monas) in Jakarta. Banning of the book Wasiat Bung Karno "Bung Karno's Legacy," edited by Masa Agung. Performance in Yogya by the Kelompok Kampungan of Putra Sang Fajar "Son of the Dawn," depicting the life of Bung Karno.

June 1, 1978 June First can be commemorated again as the anniversary of the Pancasila.

June 1, 1978 Preliminary ceremonies at the tomb renovation in Blitar.

June 21, 1978 Inauguration of the funerary complex in Blitar.

August 20, 1979 Exposition of a part of the Bung Karno Collection (paintings and other works of art) at the Taman Ismail Marzurki (15 days; 147,713 visitors).

March 14, 1980 Death of Bung Hatta.

April 4, 1980 Performance of Putra Sang Fajar in Jakarta.

May 14, 1980 Death of Fatmawati.

June 21, 1980 Commemoration in Jakarta and in Blitar of the tenth anniversary of Bung Karno's death, of the 100 days since Bung Hatta's death, and of the 40 days since Fatmawati's death.

June 23-27, 1980 Exposition on the theme: Bung Karno dan Asia Afrika "Bung Karno and Asia-Africa" in Semarang (131,500 spectators for the films; 40,835 for the photographic exposition). The exposition was to continue on, with other themes, to Den Pasar and Menado.

August 17, 1980 Inauguration of statues of Bung Karno and Bung Hatta as Proclaimers of Independence in Pegangsaan Timur, by President Suharto.

Sept. 14, 1980 Swara Maharddhika, large-scale performance by Guruh Sukarnoputra.

Sept. 15, 1980 Article by Rosihan Anwar in Kompas on the Sukamiskin letters, raising doubts about Sukarno. Arguments in the press.

June 1, $1981 \quad$ Non-authorized commemoration with Rachmawati at the Gedung Kebangkitan Nasional.

June 15, 1981 In the year following June 1, 1980, 1,458,057 visitors went to meditate at Bung Karno's grave in Blitar. 
Bung Karno is thus explainable only by divine interventions on several levels, of which we will later collect premonitory signs-"In Java, there is a prophesy that one day will come a fighting cock crowing in the East, a rooster of mixed blood, born of a hen from Bali and a rooster from Java"5_-but also by the possession of weapons and other magical objects (ajimat, pusaka), and by esoteric sciences (ilmu), the most superior of which will here be scientific (ilmiah), since Sukarno was an engineer.

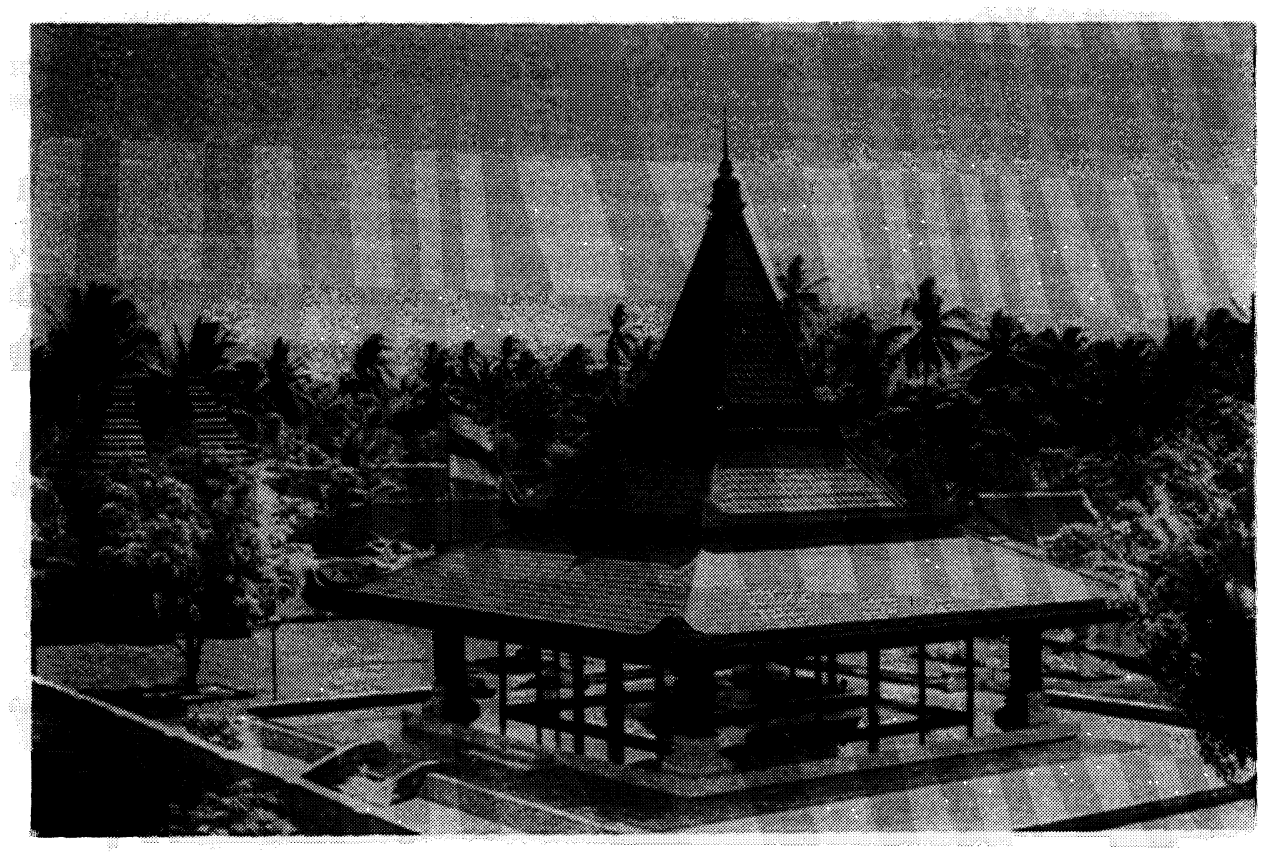

Photograph of the Javanese-style edifice (with a three-tiered roof symbolizing birth, life and death) which shelters Sukarno's tomb at Blitar.

\section{The Mystery of Origins}

On the testimony of even his own mother, ${ }^{6}$ the birth of the child was marked by supernatural signs-by the appearance of a comet (bintang kemukus) in the East, a "sign of changes in the life of humanity," and by a violent eruption of Mount Kelut, which caused widespread damage.

These extraordinary signs, along with Sukarno's unusual destiny, invalidate somehow the status of the son of Ida Nyoman Rai and Raden Soekemi Sosrodihardjo, following the idea that "great men are brought into the world only through a lineage of great men, since one's character and soul are determined by one's ancestors. . . . It is impossible that a head of State is not of royal descent."7 The only exception to this rule, according to the writer cited, would be Ken Arok, an adventurer born of the people, yet if one looks more closely, he may have descended from Brahma... .

\footnotetext{
5 Andjar Any, Bung Karno siapa yang punya? (Solo: Badan Penerbit Sasongko Solo, 1978), p. 42.

6 I.N. Soebagijo, Idayu Nyoman Rai, Sukarno anakku (Jakarta: Antar Kota, 1978), pp. 36-37.

7 Andjar Any, Menyingkap tabir Bung Karno (Semarang: Aneka, 1978), p. 6.
} 
Several hypotheses are therefore put forth. Sukarno is either:

-A son of Paku Buwono X, the proof being that all of the names of this monarch's children began with Kus- (Sukarno's first given name was Kusno, changed because he was ill and because he found its overtones unpleasant-kakus "toilet," tikus "rat").

-A son of Sarinah, the family maid, later immortalized by Sukarno as a symbolic woman of the people. The father would have been a Dutchman working on a Jember plantation, whose son inherited his open and audacious character. Raden Soekemi would thus have agreed to pass the child off as his own son.

-A descendant of Sunan Kalijogo, since Sukarno claimed this filiation in one of his speeches.

-A descendant of the kings of Pajajaran, owing to his affinities with Sunda (Marhaen, Ibu Inggit ... ), his aptitude for learning the Sundanese language, and his choice of Priangan as his final dwelling place.

It is an interesting fact that ancestral ties both natural (Paku Buwono $X$ ) and spiritual (Sunan Kalijogo) are found on the same plane. The invention of ancestors serves, of course, not only to legitimate power, but also to designate moral and political models serving as reference.

\section{The Gift of Prophesy (peramal kelas satu)}

As early as his first speeches, particularly in Indonesia Menggugat, Sukarno proclaims his faith in the liberation of Indonesia and announces upcoming major conflicts in the Pacific. ${ }^{8}$ The proclamation of independence in 1945, the realization of these national ideals that he had expressed at a moment where the majority of the inhabitants of the Dutch East Indies had not the slightest idea of such a possibility, confirm the prophetic nature of his words and project him into a long line of predictions, Joyoboyo's in particular.

This reinterpretation of Sukarno's persona seems to merge with the rumors which apparently circulated throughout Java around 1930, but of which one also finds echoes in the Surabaya press in 1928, on the imminent arrival of a King of Justice (Ratu Adil Herucokro). The newspaper Sin Po (January 13, 1930) spoke of a Kyai from Kudus selling talismans (ajimat) and announcing major changes, while the journal Darmokondo (January 8, 1930) calculated, from an interpretation of a tembang from Ronggowarsito, that that year would see extraordinary upheavals. ${ }^{9}$ Would this event be Sukarno's trial, and the Ratu Adil Herucokro or Imam Mahdi, Sukarno himself?

Furthermore, Sukarno also compared himself to the character of the wayang, Kroksono (who becomes Prabu Baladewa), abandoning his asceticism to Argoso in order to descend the mountain and bring a magical weapon destined to reunite clashing factions. Then he is kept in the background and finally reappears. The relationship to the theme of the Bharatayuda - as opposed to a New Order which would be more Ramayana-esque ${ }^{10}$ - constitutes a popular belief regarding the Sukarnian period, since the president's fate is in keeping with

\footnotetext{
8 For example in the article "Indonesianisme dan Pan-Asiatism," in Suluh Indonesia Muda, 1928, reprinted in Dibawah Bendera Revolusi, 1963, pp. 73-77.

9 Andjar Any, Bung Karno siapa yang punya? p. 94.

${ }^{10}$ See G.J. Resink's address at the Tenth Congress of Asian Historians, Yogyakarta, 1974.
} 
Baladewa's, in short, "satu nujuman yang cespleng sekali" (an absolutely effective prediction), as one author writes. ${ }^{11}$

But these Sukarnian prophesies have, in comparison with Joyoboyo or Rongowarsito, a further and higher dimension. They are the "result of neither nocturnal meditations, nor astrological calculations, nor consultations of a crystal ball."12 They are, for the first time, founded upon scientific analysis and the reading of books, modern predictions. Here again, Sukarno, at the same time prophet and prophesy of the Ratu Adil, marks the era with his innovative genius.

\section{The Thaumaturgic President (ajimat, pusaka)}

To the characteristics we have touched upon above-royal lineage, prophesies of the pujangga-popular belief adds a multitude of traits which fall within the realm of the magical powers of dukun or pawang, and of which we can only give here the examples which seem to us the most significant:

-In Bali, the people attribute to Sukarno power over rain, symbol of fertility. His visits were indeed regularly accompanied by storms and beneficial rains.

-As a child, his grandfather made him lick the wounds of the sick, which healed. The remarkable power of his tongue was "like a meteoric iron that chased away illnesses. It can even drive back the Dutch."13

-He had the eyes of the mythical cat Candramawa. This is confirmed by the American ambassador, Howard P. Jones, in his memoirs The Possible Dream, where he mentions Sukarno's magnetic gaze.

- He was capable of improvising patronymics for the infants who were often presented to him.

-The discovery of the Pancasila also attests to his status as one chosen by God.

All sorts of parallel speculations have developed concerning protective objects which guarantee his power and legitimate his superiority. These rumors are all the more fertile in the collective imagination since the possession of such objects is, by tradition, discreet, and often secret. Sukarno would thus have possessed:

-A fragment of besi kuning (magic iron) obtained in East Java and coming from a magical weapon of Menakjinggo, which, as the story goes, was broken into pieces and fell into the possession of several elected officials.

-Aji Lembu Sekilau, name of a magical iron which protected Gajah Mada and rendered him invulnerable.

-A pusaka kris from his Balinese great-grandmother who had dipped it in the blood of Dutchmen.

-The military cane that he always held in his hand was made from pucang wood ${ }^{14}$ from Kalak, near Pacitan. This wood has the distinctive characteristic, when reflected in water, of

11 Andjar Any, Menyingkap tabir Bung Karno, p. 37.

12 Ibid.

13 Ibid., p. 42.

${ }^{14}$ A species of tree. 
taking on the form of a swimming snake. What is more, this stick contained a little kris inside it.

These objects refer to famous personages both real and legendary, each associated with various forms of power: Menakjinggo is linked to the idea of a violent conquest of power, Gajah Mada is the symbol of unification, and the Balinese kris refers to the resistance against colonialism.

It must be noted that after Sukarno's death, the rumors were revived by the mysterious disappearance of all these objects and by the problem of the legacy. Although Sukarno had few personal possessions, and his collection of paintings could be considered presidential and therefore belonging to the State, the fate of his library and of the wardrobe where he kept at least his kris and his stick, which everybody would have been able to see, has not been officially clarified. The coffin in which he was placed during the three hours following his death, before it was changed for a model more befitting his rank, is piously conserved by the official morticians (paling hitam), for a future museum, despite numerous purchase offers. The same mystery enshrouds the several canvasses painted in Flores, which are priceless. Some of them belong to the collection of Adam Malik, but as for the others, it seems that the owners prefer to remain anonymous. The books of his son Guntur (Bung Karno dan Kesenangannya) - who was only able to save his father's peci, pen, razor, and cologne (Shalimar de Guerlain!) - continue to sustain, more mundanely, this cult of objects.

\title{
2. The Great Lover (pecinta agung)
}

\author{
"Pecinta agung, pecinta keindahan, pecinta kesenian, pecinta persatuan, \\ pecinta wanita." 15
}

The extent of the literature devoted to this dimension of Sukarno's personality is what most strikes the Western observer, for it quite evidently goes beyond simple anecdote in order to portray the vital syncretic vigor that was the very personality of Sukarno, and which seemed to want at times to encompass all creation. Love, the essential component of his persona, often gives the impression of knowing no limits; and it must be emphasized that women were only one aspect of this. It is the sign of conquest, of success, and it also bears the mark of creative genius and therefore of God. But it would not have incited such a mass movement had it not been placed under the heading of conviviality. The Indonesian people are, after all, associated with the panache of his career, and were drawn into this vast psychodrama where elected officials-friends, artists, women, and common people who have but one name (Sarinem, Samiun, Marhaen ... .)-are pulled out of anonymity and exposed, through the president's desires, to public admiration.

\section{The Women}

That Sukarno appeared to get carried away by the ease of his success with women, due as much to his fascinating personality as to his position as president, is a rather well-known fact. But the indulgence and admiration which come up in the analyzed works suggest, first of all, that his behavior is hardly perceived as different from that which is authorized by the tradition of the Sultan or the Susuhunan. Secondly, these women are seductive, and espe-

15 "The great lover, lover of beauty, lover of the arts, lover of women," or rather, The Great Lover, according to Hartini, in Andy Any, Bung Karno siapa yang punya? p. 237. 
cially appear in public as reinforcing the presidential aura, through complex signs that we can attempt to suggest here:

-These women contribute to the geographic and national dimension of the hero: with Utari, Tjokroaminoto's daughter, in the very specific urban context of Surabaya; with the Sundanese Inggit Garnasih; with Fatmawati from Bengkulu; with Haryati and Hartini from Java; the young Menado women Yurike Sanger and Kartini Manoppo; and finally with Ratna Dewi Sri, who represents the outside world. They are thus points in the national space, a space unified through the person of Sukarno.

-These same alliances are read in an historical perspective. Utari symbolized the nuptials between the revolutionary movement in all her youth and purity, with the seizing of Indonesian consciousness at Surabaya. Inggit is the companion of difficult moments, of prison, of exile in Endeh and Bengkulu. Fatmawati is the result of the relations between Sukarno and the Muslim circles of Bengkulu; she is the Mother as well, with an image of moral uprightness when she falls back on her family life at the time of her husband's escapades. The others appear caught in the whirlwind of younger and younger women who punctuate the accelerated personalization of the regime, until its loss. Lastly, with regard to Ratna Dewi Sri, one recalls the Putri Campa or Putri Cina, ${ }^{16}$ by which the rulers of long ago reinforced their alliances with the North,

-Obviously, these women also endow the image of the president with the dimension of virility, of fertility (rejeki), of generous seed, as well as with the analogy of the Javanese banteng of the PNI.

\section{Art and Beauty}

The privileged relationship that Sukarno had with art is perpetuated today by his collections, of which the most famous is that of Indonesian paintings. The first partial expositions (see the Chronology above) enjoyed a considerable public success. Artists and writers-like Sitor Situmorang, who wrote the preface to the catalogue Bung Karno dan Seni "Bung Karno and Art"17 - can recall memories of the grand presidential tradition, when they were invited to speak about their arts' contribution to national expression, and when their paintings decorated the walls of the palaces in Jakarta and Bogor.

Sukarno's personality also appears entangled with the vast renovation movement which aroused the Affandis, Sudjojono, Hendra Gunawan, and Henk Ngantung as interpreters of Indonesia's deep realities and aspirations. Authors of the period stress, along with the president's passion for art (keranjingan), the public and social aspect of the collection: "Buying and collecting paintings, works of art, is not, after all, the same thing as hoarding gold or diamonds." 18 The motivation of the president's choice of canvasses was not based upon any aesthetic quality or upon overly personal tastes, but rather upon the works' aptitude in expressing an authentically national tradition, which thereby associated artists to the country's construction.

Sukarno's passion for social art is further evoked with respect to all monumental forms: "Architecture, urban planning, the environment, and the organization of space are various

\footnotetext{
16 "Daughter, princess of Champa, of China" - we found this allusion twice.

${ }^{17}$ Edited by the Yayasan Bung Karno on the occasion of the presentation of the collections, Jakarta, 1979.

18 Ibid., p. 27.
} 
The Family

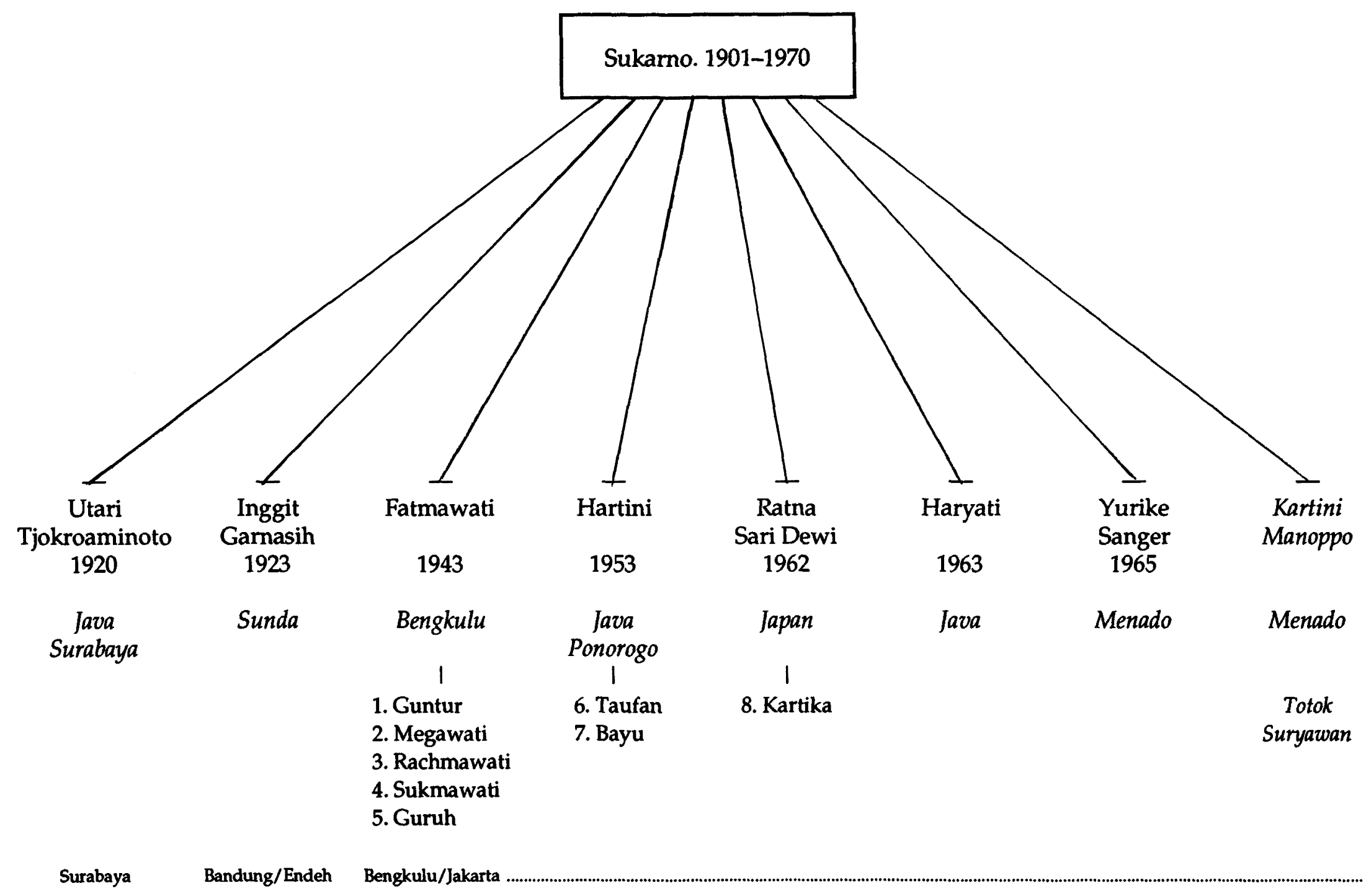


aspects of the prolongation of Indonesian tradition in Bung Karno."19 Insofar as these preoccupations strive toward harmony between human construction and the natural environment, they recall-through a mixture of reason, emotion, and romanticism-certain traits of Javanese mysticism. Foreign observers, Sitor continues, ${ }^{20}$ make a misinterpretation when they see the Sukarnian attitude based upon the mysticism of the wayang, since it leads there only by way of certain analogies.

Whatever the case may be, in 1979, Indonesians-particularly those from Jakartarealized that all of their surroundings bore the mark of Sukarno. His annotations on the sketches of the statue of the Liberation of Irian Barat, or of the Tugu Selamat Datang (Statue of Welcome), prove his direct intervention. The National Monument (Monas, symbol of the city), the beltway highway (described in the 1960 s as a "folly of grandeur"), the perspective from Kebayoran to Thamrin, the Hotel Indonesia, the Wisma Nusantara, the Sarinah department store (quite a name!), Senayan, Ancol, and the Great Mosque Istiqlal-in short, the entire present-day organization of the capital's space which corresponds to the central idea of "going to the sea" (melaut) - reflects the will of the "Architect of Indonesia." For a decade, Indonesians believed they had forgotten Bung Karno, when in reality he never ceased being there, in the scenery of their everyday lives.

\section{Love of Life}

Lastly, we have found recurring the idea of the love of life, love of peace, and horror of spilled blood-all of which suggest that the political turmoils had faded from memory, and which impose today the image of a Sukarno forever seeking unity and convergence through raising debates. Beneath the surface lie the events of 1965-1966, and one is led to believeaccording to these authors-that they are the opposite extreme of what Sukarno had always wished, and consequently outside his responsibility.

Several anecdotes are cited to support this thesis:

-The pardon of the AURI pilot who machine-gunned the palace.

-The pardon of most of the dissidents engaged in the PRRI.

-Sukarno respected life and never did any hunting. He prevented the destruction of birds' nests-and even anthills! - in the Jakarta palace.

One of the most interesting themes one finds is that of the president's non-violence. It will be recalled that marhaenism is founded upon peace, harmony, and autonomy, as opposed to other doctrines doubtless considered as more aggressive. Sukarno had high ideals for his country, and the path he proposed for the future was a collective progress, without exploitation of one class by another.

The recurrence of this theme merits sketching out an explanation. The first fact, vaguely expressed, seems to be a refusal to imagine Sukarno's implication in the troubles of 1965 , entirely rejected as the responsibility of the Communists. The period before 1965 appears in contrast as particularly peaceful and idealistic, while in fact it was often characterized by sporadic verbal violence. These images appear strongly conditioned by certain types of reactions to the economic situation of the time, which is perhaps now considered as socially more conflictive than before, due to the widening gaps in standards of living. The virtues which we attribute to Sukarno are precisely those which are not found in today's regime,

19 Ibid., p. 25.

20 Ibid. 


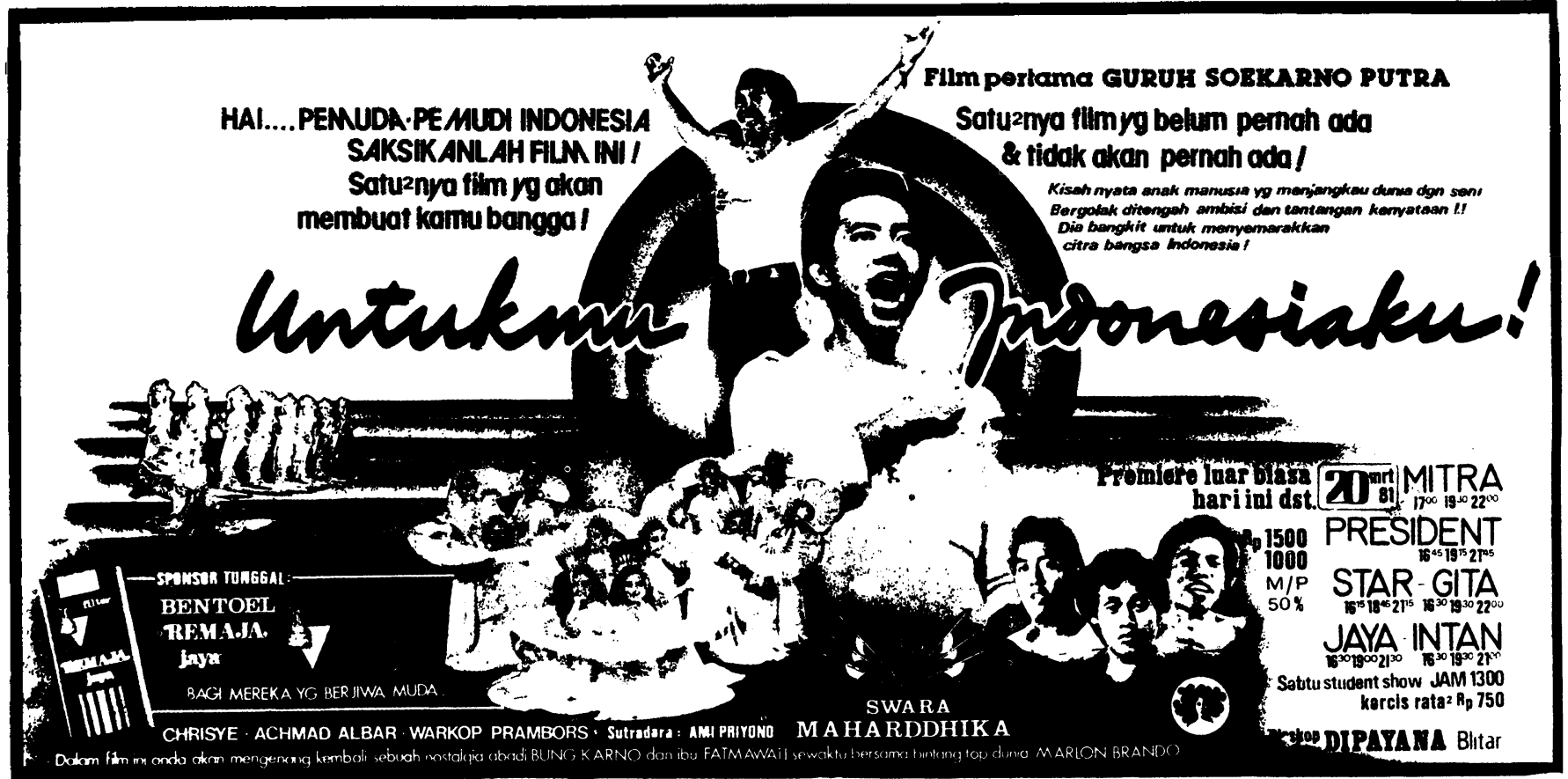

Advertisement for Guruh Sukarno Putra's film (above), Untukmu Indonesiaku "For you, my Indonesia," with Guruh. Text upper left: "Hey, you young Indonesians, come see this film. One of the rare films that will make you proud!" Bottom line text: "In this film, you will be carried away by the eternal nostalgia of Bung Karno and Fatmawati in the company of the major international star Marlon Brando" (the meeting with Marlon Brando comes from a film on Sukarno's visit, at the time of his passing through Hollywood).

and their idealization may just as well constitute an unconscious escape route, a veiled critique of present injustices.

\section{The Tragedy of Sukarno}

Parallel to the exaltation of the hero and to the image of success, another portion of this popular literature plays upon the register of pity (kasihan), of misfortune-first on the level of compassion, when it concerns the pains and hardships of Sukarno's parents in the raising of their son, with the image of the poor family, thrifty and virtuous, making sacrifices in order to ensure their son's academic and social success. Then, on a second level, we find the image of misery and solitude with the Sukamiskin prison, the exile to Endeh and Bengkulu. Lastly, we encounter the tragic horror and irony of fate which has it that, as B.M. Diah writes, "He died under a free government of the Republic of Indonesia, for the independence of which he had fought with all his might."21 Behind the image of the brilliant young man, of the engineer's success, of the president bestowed with titles, honors, and decorations as "Great Leader of the Revolution," remain quite alive the edifying clichés of the poor schoolboy, studying by candlelight at Tjokroaminoto's house, of the prisoner, of the exile, and finally of the man with dulled senses, in sandals and an undershirt, who ended his life under house arrest, alone and cut off from "this people whom he had loved so much."

21 Syamsu Hadi, ed., Tragedi Bung Karno (Jakarta: Pustaka Simponi, 1978), p. 105. 


\section{A Life Full of Privations (hidup serba kekurangan)}

The anecdotes covering Sukarno's youth are innumerable. For the most part they are taken from his mother's and sister's memoirs,22 then amplified and reinterpreted under titles like: Miskin di waktu kecil melarat di masa muda "Poor in his childhood, needy in his youth",23 Segunung penderitaan di masa kecil "A mountain of suffering in his childhood"; 24 Sengsaranya selangit "Infinite suffering." 25

It is known that, even if his parents endured doing without upon several occasions to ensure their son's future, Sukarno's youth-although very close to the people-was rather far from the poverty described in order to move the reader to pity. It was composed, rather, of thrift (Raden Sukarno was the director of a school and had bought a coconut grove, after which Sukarno's studies at THS in Bandung were paid for by Poegoeh) and especially of a sensible orientation (HBS, Tjokroaminoto), and lastly, of a great deal of individual energy. One must wonder, then, what the development of all of these childhood episodes signifies; for example those we have chosen from a comic book called Bung Karno Putra Sang Fajar "Bung Karno, Son of the Dawn":26

-The illnesses, malaria, and dysentery, which pushed him into changing his name from Kusno to Sukarno.

-A childhood of misfortune and suffering, like Abraham Lincoln's.

-Work consisting of pounding rice each morning in order to save one cent for his parents.

- He does not have the money to buy firecrackers on the day of Lebaran.

-His father is angry with him when he knocks down birds' nests.

- He is beaten by his father when he abandons watching over drying rice to play in the rice fields.

- His first love-affair with a young Dutch girl.

- The windowless room without electricity at Tjokroaminoto's house.

In the book's introduction, Guntur writes: "Children must know how the leaders of days past lived, how they exhausted their strength and their time to attain Indonesia's independence in order to understand the real meaning of the Message of the People's Suffering."

Two aspects dominate this version of Sukarno's childhood. First, the idea of necessary suffering, of poverty on the level of the people's, with which most readers identified. Then the idea that from this suffering develops, over a historic duration, a climb toward a better future, that of Amanat Penderitaan Rakyat. These true anecdotes have the function of appealing to the common reader right where he is, at the humblest rank of society, and making him follow the hero along the path of individual energy which could be his own, toward the heights. In relation to the theses of divine predestination mentioned earlier, this interpretation of the merits of personal effort refers to a notion of Man that is, if not more

22 See Bibliography below.

${ }^{23}$ S. Saiful Rahim, Bung Karno masa muda (Jakarta: Antar Kota, 1978), p. 32.

${ }^{24}$ Erka, Bung Karno, Kepada Bangsaku (Semarang: Aneka, 1978), p. 128.

25 Andjar Any, Bung Karno siapa yang punya? p. 129.

${ }^{26}$ M. Ali S., Bung Karno putra sang fajar (Jakarta, 1979), with an introduction by Guntur Soekarno. 
secularized, at least more individual and modernistic. But what is the impact of this moral in the Indonesian society of today?

\section{The Solitary Death}

Today, the context of Sukarno's death is still enveloped in mist (kabut), on account of his retreat from the political scene and the rarity of last testimonies, which are seldom found outside his close family. It is also full of shadowy areas, unanswered questions, and ambiguities. Was the president directly implicated in the 1965 coup? Was there any collusion with the PKI? Certain articles recall that no proof or clear answers have been given, ${ }^{27}$ and that the investigation built up around his involvement appeared to be intended more to keep it in the background than to shed real light upon the subject. With time, political and economic critiques have faded away. Some representatives of the 1966 generation admit the whole truth. A part of Bung Karno thus emerges in the collective memory of Indonesians under the heading of suffering (dia banyak menderita), of the victim (korban), and of solitude. A parallel with Napoleon is even drawn (the French are admired for having brought his ashes back with great pomp from St. Helene and placed them in Les Invalides, for having built the Pantheon, and for knowing how to honor great men). And one could, concerning Bung Karno, apply the very terms of Chateaubriand: "His renown is for us brought about by his misfortune; his glory benefited from his unhappiness."

The confused situation in which Sukarno died "accused but not condemned," causes the Indonesians of today to question themselves with a bad conscience, with deep-seated doubt, and a guilt complex. "All of this is our fault as a nation, if one goes by the axiom according to which a nation only gets the leaders it deserves." 28 Moreover, "when $99 \%$ of cultivated Indonesians only thought of living comfortably under the colonial period, he spent all of his time struggling against colonialism," the same author adds, while Nasution declares: "Bung Karno was already in prison for Indonesia's independence before I had any idea about the fight for Independence." ${ }^{29}$ To this are added doubts concerning the quality of medical care given to him at the end of his life. The physical suffering he endured makes his destiny appear like a calvary with mystical resonances, a martyr.

Another path for freeing oneself of this nuisance of a death consists of aestheticizing it through the fable of the creator devoured by his creation: "He attained his ideals only to be devoured by them afterwards." 30 It is true that everything in the Sukarnian lifestyle recalls the image of the fire, and of a flamboyant life ending in sacrifice. He once said of himself, "I feel like a firebrand among hundreds and thousands of others in an immense blazing furnace. I have given a little to this fire, but I have been devoured by it."

We have also found through analyzing the spirit of popular compassion, certain traits of the suffering of heroes in Indonesian novels, which originally develop upon the feeling of social leveling, with the contrast here between past power and a morally miserable end, in the expiation of a man who was great due to his superhuman qualities, but who dies of his human failings. But we especially find tragedy in the image of the final solitude of an individual definitively cut off from his own and from his people. A solitary end all the more poignant since all of Bung Karno's life had only had meaning through the contact and the

27 This is one of the main themes of B.M. Diah's article in Tragedi Bung Karno.

28 Ibid., p. 115.

29 Sonata 112 (August 1978): 10.

${ }^{30}$ This theme is quoted as a chapter heading and on the back cover of the book, Tragedi Bung Karno. 
expression of this Indonesian people (penyambung lidah rakyat), which nobody contests as being the grand passion of his existence.

\section{The New Man (manusia baru)}

The return of the concept of manusia baru-"new man"-with respect to the leader of the Orde Lama may seem rather paradoxical. However, at this end of the 1970 s, which are terminating in a certain moroseness, intellectual circles are making their disenchantment known, and the students-who did not live through the last moments of the Sukarnian regime-are asking themselves questions. To ontological questions as well as dialectical questions, one realizes that all the answers already exist in Sukarno: on foreign imperialism, on national solidarity, and on the conception of power (kepemimpinan) in Indonesia. These answers contrast more and more with those supplied by the current regime, and therefore appear as a possible alternative. At the level of discourse as well as action, the Sukarnian model thus finds itself once again available for various attempts at recuperation.

\section{The Builder (tukang membangun)}

We have already touched upon the realization of Sukarnian omnipresence in the decisions concerning urban planning in Jakarta. ${ }^{31}$ But in fact, all the touching scenes of the traditional family life of his childhood-reading in his father's school library; the invitation to Tjokroaminoto's house; the diploma in engineering from the THS in Bandung; the participation in an architect's office with Roosseno-also bring out the image of the studious will, of the zeal toward work, in short, of the pribumi effort and aptitude for enterprise (berdikari). On the one hand, there is of course the political agitator, but on the other is the determination with which he tackles his studies, an ambition for knowledge which one could opportunely recall today for the students of the ITB.

In a book already old yet still available, Solichin Salam, 32 a well-known and prolific writer, published a list of the books from Sukarno's library, a list of his 224 written works and itemized speeches, as well as of his 26 honorary doctorates, the last being from Universitas Muhammadiyah of Jakarta in Science and the Unity of God. The inflationary aspect of this rain of titles (to which must be added over twenty decorations) has faded today, and the panegyrists only retain from it the mark of an immense knowledge.

This knowledge was certainly the result of a great will, but particularly stressed is the pursuit of assimilation, the Indonesianization of foreign elements. Essentially tactical, it demonstrates that Sukarno assimilated this knowledge only to better defend himself against foreign aggression, and to succeed in battling it with his own weapons, by finding and facing foreign challenges, a purely Indonesian response. This superiority complex-found in reflections such as "You have nuclear weapons, but we have Art" for the benefit of the Americans, or for the benefit of the Soviets, telling them that their revolution is of minor consequence compared to the Indonesian Revolution ${ }^{33}$-evidently allows the youth of the 1978 generation to remain dreamers.

\footnotetext{
31 See p. 184.

32 Solichin Salam, Bung Karno Putera Fadjar.

33 Cited again by Diah, in Tragedi Bung Karno.
} 
OPINION POLL

of the visitors at the exposition Bung Karno dan Seni Jakarta. August 1979. (550 responses).

Excerpts from the 14 questions:

10. You came to this exposition because:

$\begin{array}{llr}\text { a. Bung Karno is the first President of the Republic } & 15 \% \\ \text { b. You feel nostalgic about him (rindu) } & 11 \% \\ \text { c. His collections are beautiful } & 8 \% \\ \text { d. By curiosity (sekedar penasaran) } & 2 \% \\ \text { e. You want to understand who Bung Karno really was } & 56 \% \\ \text { f. For want of anything better to do } & 1 \% \\ \text { g. You like him } & 15 \% \\ \text { h. Other reasons } & 15 \%\end{array}$

14. What are your impressions?

$\begin{array}{lr}\text { a. Admiration (kagum) } & 39 \% \\ \text { b. Enthusiasm (bersemangat) } & 16 \% \\ \text { c. Sadness (sedih) } & 3 \% \\ \text { d. Happiness (gembira) } & 5 \% \\ \text { e. Emotion (terharu) } & 18 \% \\ \text { f. Pride (bangga) } & 40 \% \\ \text { g. Mundane impression (biasa-biasa saja) } & 2 \% \\ \text { h. Discontent (tidak senang) } & 0 \% \\ \text { i. Others } & 9 \%\end{array}$

This concept of the new man, therefore, allows greater importance to be given to the president as engineer, accentuating his education by individual effort and the Sukarnian participation in the construction of the country, thus erasing the aspects of his political action currently judged undesirable. Nor is it surprising that Frans Seda could remark in the visitors' book at the Bung Karno exposition: "Juga dia telah membangun" (He, too, has built).

\section{Islam on the Move}

If the relations between Sukarno and the Muslim parties were often conflict-ridden, and if some aspects of his personal nature-like his taste for festivals, or his participation in certain mystical ceremonies (in Kalibata, for example)-were suspected of being tinged with paganism or a return to Hindu tradition, 34 it nonetheless remains that among the multiplicity of facets of his persona, many of them are still susceptible to drawing enthusiastic support from the upholders of an innovatory Islam.

In fact, Sukarno never missed the opportunity to proclaim-among his many allianceshis tie to Islam. And it is in this perspective that his exile in Endeh and Bengkulu lends itself to being interpreted as part of the fight for a renovation of Islam. Today one would call it "secularization" (sekularisasi). Over this period, he kept up a regular correspondence with T.H. Hassan-a professor from Bandung-on Islamic problems, deplored the ignorance and conservatism of the kyai of Endeh, and had numerous debates with people from the Mohammadiyah of Bengkulu. The authors we have studied do not neglect to recall Sukarno's various declarations against the taklid, seen as "narrow-mindedness, blind and short-sighted belief," and on the idea of a dynamic Islam, often taken in substance from Ataturk: "Islam

34 An accusation made partiuclarly in the Constituent Assembly debates. See Pantjasila, Trente années de débats politiques en Indonésie (Paris, 1981), p. 130. 
does not drive people to sit around all day, to dream in mosques, to say one's beads over and over again. Islam is a fight (Islam adalah perjuangan)."35

One book, Bung Karno, Milik Rakyat Indonesia, by someone named Bung Mawi, ${ }^{36}$ presents itself as a Penilaian Ummat Islam terhadap Pribadi Bung Karno "Judgment of the Muslims on the Personality of Bung Karno," and constitutes a sort of apologia of Bung Karno's superiority, thanks to divine intervention. This book's emphasis organizes itself around the following themes:

-Bung Karno believed in the unicity of God (jiwa ketuhanan yang Maha Esa), unicity here confused with Islam, with the Nation, and with the Pancasila. Unlike some universities rather embarrassed by their conferral of honorary doctorates before 1965, Bung Mawi does not renounce that of Doktor Ilmu Tauhid. ${ }^{37}$

-The elevation of Sukarnian ideals to attain independence for the country.

-The never-ending struggle (tidak menegal lelah) for fighting not only against colonial ism and imperialism, but especially against feudalism.

-His audacious (berani) attitude which consisted of designating his enemies outright, to bring them down certainly, but also to confer their existence on them by naming them. This courage conflicts, of course, with the latent mistrust with which the Muslim opposition is surrounded today.

-Bung Karno had a moral doctrine which, through struggling, gave life a new meaning and oriented time toward a better future, without bending to "any man or any myth, because Islam forbids it." 38 All of these remarks hinge upon the following idea: God had given Sukarno superior qualities, but also human weaknesses. Thus, in the supernatural and divine nature of the Sukamian revolutionary dynamic, as in his fall from power due to alltoo-human weakness, Muslims find the familiar apologetic terrain of their religion. Sukarno's destiny, therefore, constitutes a magnificent parable of divine greatness and power. To the last man, Indonesia's Muslims have the greatness to respond, like Hamka, with forgiveness: "I am bound to the promise of Allah which says that, even if the amount of sins is infinite, provided that one asks forgiveness, he will be forgiven by Him." 39 The Muslims devote themselves to taking over as the holder of universal ideals.

\section{The Images of Power (kepemimpinan)}

It is also appropriate to wonder as to the basis of, in the years studied herein, the repeated evocation of the characteristics of authority (sifat-sifat kepemimpinan). Neither the disenchantment of Indonesian society, nor governmental action for the training of veritable corporate chiefs - which have provoked the appearance on the market of all sorts of evaluation tests and methods for achieving success-suffice to explain the return to the Sukarnian

35 this extract of a 1936 letter is reprinted in Soewarto, Kejayaan dan saat-saat akhir Bung Karno (Jakarta: Gunung Jati, 1978), p. 71.

36 Jakarta: Rose Group, 1978. Bung Mawi still claims to be Putra Petani, Pencinta Tanah Air.

37 This was the last honorary doctorate degree given to Sukarno "dalam falsafat Ilmu Tauhid," by the Universitas Muhammadiyah, August 3, 1965, in Jakarta.

38 Bung Mawi, Bung Karno milik rakyat Indonesia, p. 48.

39 "Kenang-kenangan Buya Hamka. Pernah jadi teman, pernah jadi lawan Bung Karno," in Sonata 110 (July 1978): 69. It basically concerns an article published in Pedoman, July 25, 1970. 
model. Apart from these contingencies, we should also stress the permanence of a more particularly Javanese questioning (and for good reason!) on the morality of power and the qualities suitable for a leader of the people (pemimpin rakyat).

\section{The Relationship with History}

Sukarno's ancestry places him in a great anticolonialist historical tradition. Through his mother, he receives the heritage of the Balinese resistance and the Perang Puputan. Through his father's line, he is the guardian of the soul of the Javanese resistance embodied in Nyi Ageng Serang, a woman who fought beside Diponegoro. ${ }^{40}$

In this perspective, Sukarno-who did not need to remake his own genealogy-finds himself at the confluence of the ancient histories of Bali and Java, a place predestined for a new historic destiny; and it is exactly this which seems to legitimize him in the popular tradition which, unlike ours, does not distinguish between myth and history.

\section{The Relationship with the People}

The manner in which Sukarno calls out directly to the masses-haranguing them, making them participate directly in the psychodramas of his grand ideological genesesremains for all Indonesians who knew him, a vibrant memory of which all the works testify: "The people would have continued to acclaim Bung Karno if he had asked them to eat stones rather than receive the aid of the United States." 41 This feeling of being associated with action, of being called to witness, certainly represents the essential change in the practice of power in Java in the time of Sukarno. And the temptation is strong to mention here the very fashionable notion of the "spectacle State," as if every State was not precisely a spectacle whose layout and changes can only be revealing.

This privileged relationship with the people has a particular dimension as well, for it is marked by generosity, conviviality, and love. The gift he made in the appearance of his person to the people (dia banyak memberikan kepada kami), the love of the homeland (cinta pada tanah air), the idea of sacrifice (pengorbanan) that Nasution himself willingly recognizes, gives to the already semi-legendary personage an exceptionally human and close connotation. His inventiveness in ideological matters is constantly raised, at least within the authorized limits: nationalism, active neutrality, Marhaenism, and especially Pancasila, which has demonstrated its quality, since it has stood the test of time, since it is more than ever the "source of all sources" (sumber dari segala sumber). Although the rehabilitation of his ideas does not go beyond 1950, with the principal speeches of August 17-from Sekali merdeka tetap merdeka "Once free, always free"(1946), to Dari Sabang sampai Merauke "From Sabang to Merauke" (1950)—this genius of ideas (pintar menyusun gagasan) is more than ever living in the memories, as well as in certain themes, which still stir people into action.

Lastly we must classify under this same aspect the titles such as Keluarga Sukarno tidak ada yang kaya "Nobody in Sukarno's family is rich" or "Sukarno never gave any important post to a family member," or the supposedly forthcoming memoirs of Manggil, who reports that the president had dreamed of buying himself a house, but did not have enough money. ${ }^{42}$ All of these anecdotes, passed on, transformed, add to the familiarity that Sukarno

\footnotetext{
${ }^{40}$ See Mashoed Haka, Dunia Nyi Ageng Serang, Wanita pejuang bangsa (Jakarta, 1976).

41 Tragedi Bung Kamo, p. 112.

42 Announced in Sinar Harapan, March 29, 1981, p.1.
} 


\section{Genealogy of Sukarno}

BALI

Raja of Buleleng removed by the Dutch

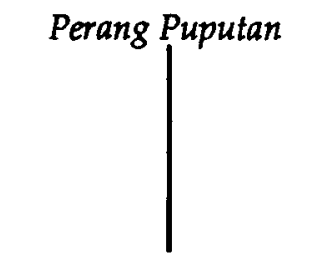

Idayu Nyoman Rai (his mother)

(Balinese religion
MOJOPAHIT

Sultan of Kediri<smiles>[CH]1[CH]CC1</smiles>

Nyi Ageng Serang

Diponegoro War (Pahlawan Nasional) National Hero

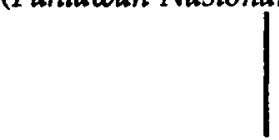

Raden Soekemi Sosrodihardjo (his father)

Islam/theosophy religion

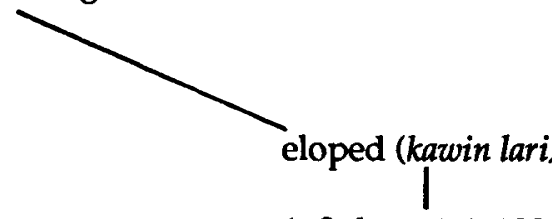

1. Sukarmini. 1899

2. Kusno (Sukarno). 1902

NB. The descent of Sukarno's father from Nyi Ageng Serang is clearly indirect.

inspired in the Indonesian people, and for which the absence of the money barrier is retrospectively considered particularly sensitive.

\section{The Regard of the Outside World}

The photos so often reproduced of his meeting with the Pope, with Kennedy, with Sihanouk - not forgetting his wax image at Madame Tussaud's, between Gandhi, de Gaulle, and Castro, which has since, however, been removed-also maintain the legend of the leader of the Third World, for this international recognition has an essential function. Indeed, to exist, to be Indonesian and independent, naturally amounts to being recognized as such in the eyes of the world. It is the duplication of the regard of the other which confirms, through the person of Sukarno, the very existence of Indonesia, which, thanks to him, is considered, named, and recognized as such (bangsa bernama).

By the same token, articles like "Bung Karno di mata para penulis Barat,"43 contribute to the reflection, through the existence of the president, of the image of an Indonesia finally raised to a level of dignity and speaking on equal terms with the world's great ones.

Among the works which recall this emergence as it was symbolized by Sukarno, one book, Perjalanan Bung Karno. Mengenal sejarah dan tanah airnya adalah suatu kewajiban bagi setiap orang [The journey of Bung Karno. To know his homeland and its history is a supreme

${ }^{43}$ In Matahari 1,6 (August 16, 1978): 10-14. 

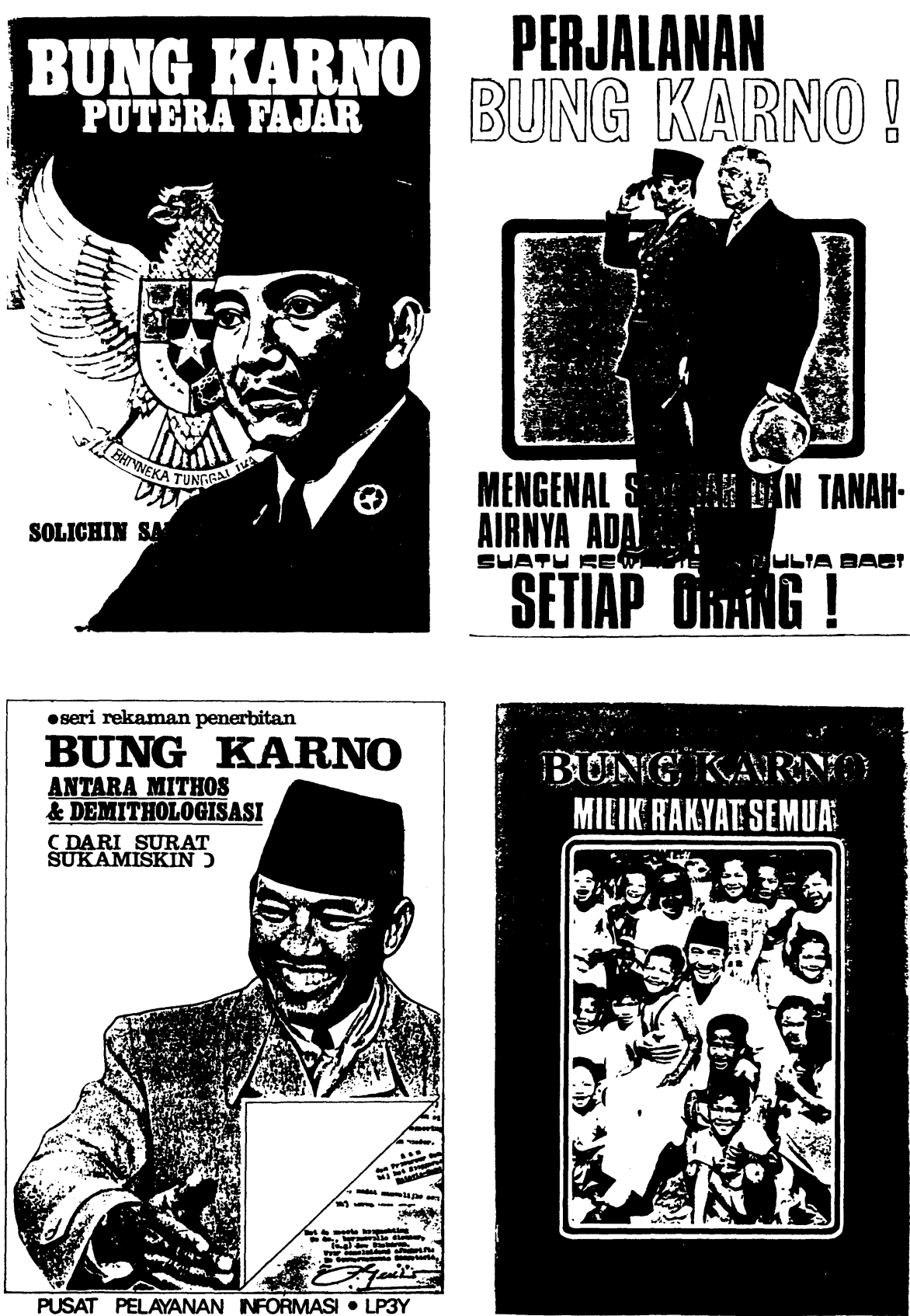

Examples of books cited. Cf. Bibliography. 
duty of each person], is one of the most unexpected in today's context, since it concerns itself with Sukarno's visit to the USSR in 1956. This book, distributed and edited by the Yasasan Multatuli of Bogor, relates the foundations of a "pure friendship" (persahabatan yang murni) between the Indonesian and Soviet peoples. It also brings up the significance of this return of the figure of Bung Karno. Indeed, to untangle that which arises from popular spontaneity, from commercialization, and from political intentions requires delicate research, whereupon the affair of the Sukamiskin letters could also serve as a subject for reflection.

\section{The Sukamiskin Letters}

The commander's statue had hardly been put back on its pedestal when a new blow struck him, with the revelation of the Sukamiskin letters. Let us briefly recall the facts: in his book Road to Exile, The Indonesian Nationalist Movement 1927-1934, John Ingleson refers to four letters written by Sukarno while he was imprisoned at Sukamiskin, to ask pardon from the public prosecutor and to swear never again to involve himself in politics. Several researchers had already learned of these archival letters, but hardly reported on them insofar as they were non-authenticated copies, and added nothing determining to Indonesia's history. But the fact had not been brought in front of Indonesian public opinion before an article by Rosihan Anwar appeared in Kompas. ${ }^{44}$

It is not for us to judge here the historical value of these letters, but rather to analyze the effects of this attack on Sukarno's image. For the reactions are extremely vivid: "I was stunned," writes H. Mahbub Dhunaidi, "if a tiger had entered my room, I would have let it be, like a cat." 45 "I was stunned, too," writes M. Roem, while Adam Malik preached moderation: "It no longer serves any purpose to put into question problems concerning Sukarno, because he is no longer here." 46

For many readers, it appears more probable that the letters were a fake, made at the time by the Dutch police; and Rosihan Anwar, likened to Ingleson, is accused by Sitor Situmorang of replaying the colonialist game of fifty years earlier, and of being "a mediocre individual, incapable of understanding his own nation's history."47

Supposing that Rosihan Anwar had actually sought to downplay Sukarno's role, indeed even to discredit him as "easily bending his knees," it is interesting to note that the result is a general nationalist outcry wherein Indonesians instinctively tighten ranks as if facing a colonialist subversion (also meriting analysis would be the Indonesian reactions of pride and irritation over the foreign appropriation of Bung Karno's persona): "They (foreigners) are fascinated by Sukarno because they consider him as something exotic, while they feel more at ease with Bung Hatta." 48 Between the insidious destruction of the myth that Rosihan Anwar indulges in, insisting upon the divergences between Sukarno and Hatta, and the nationalist reflex to come to his defense, the staff historians Ong Hok Kham and Taufik Abdullah try to dismiss as too intellectual for the public, the distinction between the private man and public figure. But the proof is there, that doubtlessly for a long time, the Indonesian nation has largely identified itself with Sukarno.

\footnotetext{
44 Rosihan Anwar, "Perbedaan analisa politik antara Sukarno dan Hatta," in Kompas, September 15, 1980.

45 Kompas, October 7, 1980.

46 Ibid., January 25, 1981; for M. Roem and Adam Malik see Tempo, February 28, 1981.

${ }^{47}$ Merdeka, February 19, 1981.

48 Majalah Zaman 2, 23 (March 1-7, 1981).
} 
Although the period we have just analyzed is extremely brief in the eyes of history, it gives the idea of the multiplicity and complexity of the Bung Karno phenomenon, a polymorphous model wherein anyone can identify himself in some way. Moreover, the importance of his role in recent national history makes for his becoming a core around which certain social confrontations crystallize for the appropriation of the symbol: Bung Karno siapa yang punya? "Who possesses Bung Karno?" He was already the sovereign, the Muslim, the nationalist, the builder; he is appealed to as much for unity as for division. Today's students, who see in him the image of the unknown Father, recall his ghost in books like Wawancara imaginer dengan Bung Karno "Imaginary Interview with Bung Karno." 49 Others set out to revive the political message to give more consistency to the opposition. As the reader will have understood, this reactivation of the engineer or of President Sukarno subtly implies a negative value judgment on his successor, an intention which does not escape a public familiar with the interpretation of allusive processes. Bung Karno's installation into the national perspective, then, is both necessary-for one party like the other-but delicate in the art of salvaging pieces of the historical figure without bringing back to life the old demons from Indonesian history. But wherever the pedestal upon which Bung Karno will finally be installed, it is hardly rash to think that no political establishment will be able to do without him, or without the Pancasila. A simple matter of dialectics.

\section{Annotated Bibliography}

The most recent bibliography of Sukarno's writings (1,079 titles) and of writings on Sukarno (71 titles) can be found in:

Bung Karno, Sebuah bibliographi, Jakarta, Yayasan Idayu, 1979, 84p. Reedited in 1981, 130p.

\section{Books:}

Andjar Any, Menyingkap tabir Bung Karno, Aneka, Semarang, 1978, 168 p. Mostly anecdotes.

Andjar Any, Bung Karno siapa yang punya?, Badan Penerbit Sasongko Solo, Solo, 1978, 256 p. Multitude of anecdotes.

Bung Karno kenang-kenangan kepergiannya, s.l., s.d., 40 p. On the funerals.

Bung Karno dan Seni, Jakarta, 1979, 68 p. It concerns the catalogue of an exposition of a part of the Bung Karno collection at the TIM. Sitor Situmorang's article.

Bung Karno antara mithos dan demithologiasi (dari surat Sukamiskin), Yogya, Pusat Pelayanan Informasi, LP3Y, 1981, 50 p. Reprinted articles relative to the controversy surrounding the Sukamiskin letters.

Perjalanan Bung Karno, s.l., Yayasan Multatuli Bogor, 1978, 112 p. Photos and text on Sukarno's trip to the Soviet Union in 1956.

Bung Mawi, Bung Karno milik rakyat Indonesia, Rose Group, Jakarta, 1978, 52 p. A Muslim's point of view?

Erka, Bung Karno, Kepada bangsaku, Aneka, Semarang, 1978, 202 p. Anecdotes.

Erka, Bung Karno, Perginya seorang kekasih, suamiku, kebanggaanku, Aneka, Semarang, 1978, 218 p. On Sukarno's wives.

Fatmawati, Catatan kecil Bung Karno, I., Dela Rohita, Jakarta, 1978, 218 p. Abundant and original iconography on the Bengkulu period, with the initial collaboration of Sitor Situmorang.

Guntur Soekarno, Bung Karno, bapakku, kawanku, guruku, Dela Rahita, Jakarta, 1978, 270 p. Numerous anecdotes on Bung Karno's family life by his oldest son.

49 This book by Christianto was banned in 1978 . 


\section{Pierre Labrousse}

Guntur Soekarno, Triwikrama generasi muda, Dela Rohita, Jakarta, 1979, 166 p. Collection of articles (1973-78) to reawaken hope in Indonesian youth with the example of national combat.

Guntur Soekarno, Bung Karno dan kesayangannya, Karya Unipress, Jakarta, 1981. 218 p. New anecdotes.

Swara Maharddhika, Jan. 1979. Show program for Guruh Sukarno Putra.

Husmi Lain, Mengenang proklamator RI, Soekarno-Hatta, Kreasi Jaya Utama, Jakarta, 1980, 152 p. After M. Hatta's death, yet another account of the proclamation of independence.

Ramadhan KH, Kuantar ke gerbang. Kisah cinta Ibu Inggit dengan Bung Karno, Sinar Harapan, 1981, 466 p. Account of the successes of Bung Karno's romantic (and Sundanese) years from the confidences of Ibu Inggit, faithful and courageous companion of the difficult years.

S. Saiful Rahim, Bung Karno masa muda, seperti dituturkan oleh lbu Wardoyo, kakak kandung Bung Karno kepada wartawan: S. Saiful Rahim, Antar Kota, Jakarta, 1978, 34 p. Memories of Bung Karno's older sister, still living.

Soebagijo I.N., Idayu Nyoman Rai, Sukarno anakku, Antar Kota, Jakarta, 1978, 80 p., first edition 1949. Memories of Sukarno's mother often repeated afterwards.

Soewarto, Kejayaan dan saat-saat akhir Bung Karno, Gunung Jati, Jakarta, 1978, 272 p. Indonesian translation of World Star magazine, edited in Jakarta.

Solichin Salam, Bung Karno dan kehidupan berpikir dalam Islam, Widjaya, Jakarta, 1964, 134 p. Old book brought back out of storage.

Solichin Salam, Bung Karno putera fadjar, Jakarta, Gunung Agung, Jakarta, 300 p., reedited in 1981. Interesting book, which Gunung Agung had inopportunely printed in 1966.

Solichin Salam, Bung Karno di mati bangsa Indonesia, Dela Rohita, Jakarta, 1980, 116 p. Accounts of contemporaries.

Solichin Salam, Bung Karno dalam kenangan, Pusaka, Jakarta, 1981, 274 p. The golden book with the memories of all the great names of Indonesia.

F.A. Suprijatna, Bung Karno milik rakyat semua, Dela Rohita, s.d., 112 p. Reprinting of various articles and passages from books already cited.

Suripto, Bung Karno. Hari-hari terakhirnya, Grip, Surabaya, s.d., 62 p. The death and the funerals.

S. Suyountoro, Sukarno-Hatta-Soeharto menggembleng bangsanya, Bina Ilmu, Surabaya, 1980, 140 p. Why wasn't the foundation of this book cited: the Pancasila?

Syamsu Hadi, Tragedi Bung Karno, perjalanan terakhir seorang proklamator, Pustaka Simponi, Jakarta, 1978, 160 p. Reedition of articles, particularly by B.M. Diah, which appeared around 1970.

Muhammad Tito, Kumpulan kata-kata pilihan Bung Karno, Blitar?, 1980, 40 p. The little red-and-white book.

Kenangan lama, koleksi pidato-pidato Bung Karno, 45-50, s.l., s.d., 184 p. From August, 1945 to Dari Sabang sampai Merauke.

80 Tahun Bung Karno, edited by Aristides Katoppo, Sinar Harapan, Jakarta, 1981, 342 p. With 25 articles by Indonesian personalities from Sayuti Melik, Mochtar Lubis, Nugroho Notosusanto to Buyung Nasution ... published after the editing of our article. Very interesting for the reflection upon the lessons of the Sukarnian experience (democacy, law, humanism ...) as an alternative to the current political situation.

\section{Illustrated for Children:}

M. Ali S., Bung Karno putra sang fajar, Jakarta, 1979.

\section{Newspapers:}

We utilized the documentation of Yayasan Idayu, that is to say around 100 articles published in the press from 1978 to September 1981. 